\title{
THE TABOO OF PRECEDING SISTER IN MARRY: A MINANGKABAU SOCIO CULTURE ANALYSIS
}

\author{
Shafra \\ Institut Agama Islam Negeri Bukittinggi, \\ Sumatera Barat, Indonesia \\ shafraelhaqqi@gmail.com

\section{Yulia Rahmi} \\ Institut Agama Islam Negeri Bukittinggi, \\ Sumatera Barat, Indonesia \\ yuliarahmi796@gmail.com
}

\begin{abstract}
Ideally in the family, the order of marriage starts from the eldest child then followed by the second child, the third child and so on. However, there are some cases the youngest child preceded the older brother or sister in marry. In many areas, this phenomenon is a common one. It doesn't matter if the siblings who is being preceded is a man or a woman. However, in Tabu Baraie Nagari Paninjauan Tanah Datar, preceding older sister in marry is a taboo. It is said that if it is done, the older sister will stay single. This research objective is to find out the origin of the taboo of preceded sister marriage viewed from socio culture analysis.
\end{abstract}

Abstrak : Idealnya di dalam keluarga, urutan menikah dimulai dari anak sulung. Kemudian disusul anak kedua, anak ketiga dan seterusnya. Tapi seringkali realitanya tidak demikian. Si bungsu mendahului kakaknya untuk menikah. Di banyak daerah, melangkahi kakak dalam menikah adalah hal lumrah. Tidak menjadi soalan, apakah yang dilangkahi nikah, kakaknya itu perempuan atau laki-laki. Akan tetapi di Tabu Baraie Nagari Paninjauan Tanah Datar, melangkahi kakak menikah, khususnya kakak perempuan merupakan pantangan. Terlarang bagi adik mendahului kakaknya untuk menikah, jika kakaknya perempuan. Umumnya kakak perempuan yang dilangkahi nikah oleh adiknya, hidupnya melajang. Tujuan penelitian ini adalah untuk mengetahui asal usul pantangan melangkahi nikah kakak perempuan dalam kajian sosiologis.

Kata kunci : perkawinan, melangkahi nikah, kakak perempuan. 


\section{PENDAHULUAN}

Secara normatif, tidak ditemukan nash ayat atau hadis yang mengatur tentang urutan menikah dalam keluarga. Juga tidak ada larangan melangkahi nikah kakak perempuan. Apabila sudah sampai waktunya, maka siapa pun dianjurkan segera menikah. Akan tetapi dalam keluarga tertentu dan budaya tertentu, terlarang bagi seorang adik menikah lebih dahulu dari kakaknya. Jika kakak tertua adalah laki-laki, maka tidak ada pantangan jika adiknya mendahuluinya menikah. Namun tidak demikian halnya dengan perempuan. Seorang adik terlarang melangkahi nikah kakaknya yang perempuan. Larangan melangkahi nikah kakak perempuan bagi adik laki-laki atau pun perempuan itu, berlaku di Tabu Baraie Nagari Paninjauan Tanah Datar. Sebagai gambaran berikut rincian dalam tabel :

Data kakak yang dilangkahi nikah

\begin{tabular}{|c|l|l|l|}
\hline No & $\begin{array}{l}\text { Nama } \\
\text { Dusun }\end{array}$ & $\begin{array}{l}\text { Nama } \\
\text { Suku }\end{array}$ & $\begin{array}{l}\text { Jumlah } \\
\text { Kakak }\end{array}$ \\
\hline $\mathbf{1}$ & Banto & Pisang & 2 \\
\hline $\mathbf{2}$ & $\begin{array}{l}\text { Kubu } \\
\text { Sarimbang }\end{array}$ & Koto & 3 \\
\hline $\mathbf{3}$ & $\begin{array}{l}\text { Kubu } \\
\text { Sarimbang }\end{array}$ & Pisang & 2 \\
\hline $\mathbf{4}$ & $\begin{array}{l}\text { Bulakan } \\
\text { Tabek }\end{array}$ & Pisang & 2 \\
\hline $\mathbf{5}$ & $\begin{array}{l}\text { Tabu } \\
\text { Baraie }\end{array}$ & Panyalai & 7 \\
\hline $\mathbf{6}$ & $\begin{array}{l}\text { Tabu } \\
\text { Baraie }\end{array}$ & Sikumbang & 2 \\
\hline
\end{tabular}

\begin{tabular}{|c|l|l|l|}
\hline $\mathbf{7}$ & $\begin{array}{l}\text { Tabu } \\
\text { Baraie }\end{array}$ & Koto & 1 \\
\hline $\mathbf{8}$ & Limpauang & - & - \\
\hline $\mathbf{9}$ & $\begin{array}{l}\text { Cubadak } \\
\text { randah }\end{array}$ & - & - \\
\hline $\mathbf{1 0}$ & Anak Kayu & - & - \\
\hline $\mathbf{1 1}$ & Data & - & - \\
\hline $\mathbf{1 2}$ & $\begin{array}{l}\text { Kandang } \\
\text { Baru }\end{array}$ & - & - \\
\hline & $\begin{array}{l}\text { Jumlah } \\
\text { keseluruhan }\end{array}$ & & 19 \\
\hline
\end{tabular}

Sumber Data : Hasil pendataan kakak yang dilangkahi sejak tahun 2010- 2018 yang diolah dari berbagai sumber

Tabu Baraie adalah satu dari empat jorong yang ada di Nagari Paninjauan, sekitar $37 \mathrm{~km}$ dari pusat KabupatenTanah Datar dan $3 \mathrm{~km}$ sebelah timur dari Kantor Kecamatan X Koto. Untuk mencapai Jorong Tabu Baraie dari jalan utama atau jalan raya, bisa dijangkau dengan kendaraan roda dua atau pun roda empat. Secara Administrasi Jorong Tabu Baraie, Sebelah Utara berbatas dengan Hutan Negara / Gunung Merapi, Sebelah Timur berbatas dengan Jorong Hilie Balai, Sebelah Selatan berbatas dengan Kota Padang Panjang, dan Sebelah Barat berbatas dengan Nagari Panyalaian.

Jorong Tabu Baraie memiliki beberapa pembagian daerah kecil yaitu; Banto, Limpauang, Cubadak Randah, Anak Kayu, Kubu Sarimbang, Bulakan 
Tabek, Data, Kandang Baru. Wilayah Jorong Tabu Baraie terletak di dataran tinggi kaki gunung merapi yang topography-nya bergelombang atau berbukit. Dengan luas wilayah lebih kurang $430 \mathrm{Ha}^{18}$

Masyarakat Jorong Tabu Baraie didominasi suku Panyalai. Suku Panyalai adalah penduduk asli masyarakat Jorong Tabu Baraie. Selain suku Panyalai, suku lainnya yang juga ada di Tabu Baraie Nagari Paninjauan Tanah Datar adalah suku Sikumbang, suku Koto, dan suku Pisang. Masing-masing suku dipimpin oleh panghulu, dibantu oleh panungkek (wakil kepala suku), dan labai / tumangguang sebagai pembantu wakil. ${ }^{19}$

Sehubungan dengan pantangan melangkahi nikah kakak perempuan ini, maka pantangan ini mesih eksis di Tabu Baraie Nagari Paninjauan Tanah Datar. Dari itu, dalam artikel ini akan disajikan tentang pantangan melangkahi nikah kakak perempuan dan latar belakangnya, dan ketika pantangan ini dilanggar, bagaimana pula cara menyelesaikannya sehingga dampak yang ditimbulkannya bisa

\footnotetext{
18 “Arsip Nagari Paninjauan Geografi Dan Topografi Nagari," 2017, 15.

${ }^{19}$ Panghulu bertugas hanya menerima laporan permasalahan dari panungkek, dan panghulu juga memutuskan permasalahan yang disampaikan oleh panungkek, intinya yang bekerja adalah panungkek. Sedangkan labai sama dengan alim ulama atau ustad yang kerjanya adalah misalkan pergi melayat kalau misalnya ada orang meninggal, memandikan jenazah, pergi menghadiri acara syukuran dan sebagainya. Apabila misalkan ada labai suku yang tidak mengikuti atau menghadiri acara keagamaan tertentu, maka dia akan menjadi aib bagi kepala suku yang lain., n.d.
}

diminimalisir. Apakah peran ayah sebagai wali mujbir dalam konsep fikih dilaksanakan atau tidak ? Serta bagaimana pula peran mamak dalam menyelesaikan persoalan ini sesuai pepatah Minang kusuik nan ka manyalasaian dan karuah nan ka manjaniahan.

Pemilihan daerah ini dengan pertimbangan karena struktur adat itu masih lengkap, seperti penghulu, panungkek, dan labai / tumangguang. Pantangan melangkahi nikah kakak perempuan ini akan ditinjau secara sosiologis. Mengingat masyarakat Tabu Baraie Nagari Paninjauan Tanah Datar adalah bahagian masyarakat Minangkabau. Di mana di dalam Minangkabau berlaku pepatah adat basandi syarak, syarak basandi kitabullah. Sedangkan di dalam syarak tidak ditemui pantangan melangkahi kakak perempuan. Oleh karena itu perlu dilakukan tinjauan sosiologis atas pantangan melangkahi kakak perempuan yang berlaku di Tabu Baraie Nagari Paninjauan Tanah Datar tersebut.

\section{METODE PENELITIAN}

Metode pendekatan dalam tulisan ini didasarkan pada metodologi field research (penelitian lapangan) dengan menggunakan analisis deskriptif kualitatif yaitu menggambarkan kejadian dan fenomena yang terjadi di lapangan sebagaimana adanya sesuai dengan kenyataan yang ada. Dimana penelitian menguraikan kenyataan tentang "Pantangan Melangkahi Nikah Kakak Perempuan : Analisis Sosiologis Budaya Minangkabau Di Tabu Baraie Nagari 
Paninjauan Tanah Datar". Data dikelola menurut uraian dari informasi yang didapatkan dari objek yang diteliti. ${ }^{20}$ Pendekatan deskriptif kualitatif dirasa sangat cocok, karena pendekatan kualitatif adalah suatu prosedur penelitian yang menghasilkan data-data bersifat deskriptif dalam bentuk kata-kata tertulis atau lisan dari orang-orang dan perilaku yang diamati. Adapun latar dan waktu penelitian dilakukan pada bulan Juni sampai Desember 2018. Yang berlokasi di Tabu Baraie Nagari Paninjauan Tanah Datar.

Instrumen penelitian yang digunakan dalam penelitian ini adalah pedoman wawancara, berupa daftar pertanyaan wawancara, guna mendapatkan data dari adik yang melangkahi, kakak yang dilangkahi, pemuka adat, niniak mamak, serta tokoh masyarakat dan masyarakat Tabu Baraie Nagari Paninjauan Tanah Datar. Instrumen tambahan lainnya yang berguna untuk menunjang kelengkapan data adalah, buku catatan, dan pena.

Adapun sumber data yang dipakai adalah data primer (primary data) dan data sekunder. Data primer yang menjadi sumber utamanya adalah kakak perempuan yang dilangkahi, adik yang melangkahi, pemuka adat, niniak mamak, serta tokoh masyarakat dan masyarakat Tabu Baraie Nagari Paninjauan Tanah Datar. Di samping data primer, juga dipakai data sekunder (secondary data). Data sekunder adalah data tambahan yang diperoleh dari buku-buku, serta karya ilmiah lainnya

${ }^{20}$ Suharsimi Arikunto, Dasar-Dasar Evaluasi Pendidikan (Jakarta: Bumi Aksara, 2009), 213. yang berhubungan dengan larangan pernikahan.

Selanjutnya terkait dengan teknik pengumpulan data dilakukan dengan observasi partisipatif, yaitu melakukan observasi secara lebih cermat. Dengan demikian dapat diperoleh kepastian dan sistematika data tentang apa yang diamati. Dalam observasi ini, peneliti terlibat dengan kegiatan sehari-hari orang yang diamati atau digunakan sebagai sumber data penelitian. Saat melakukan observasi, peneliti berpartisipasi dalam melakukan apa yang dilakukan sumber data, dan berbagi suka dan duka. Dengan observasi partisipatif ini, data yang diperoleh akan lebih lengkap dan tajam. ${ }^{21}$

Kemudian teknik analisis data dilakukan secara deskriptif kualitatif, yaitu interpretasi terhadap data yang diperoleh untuk mendapatkan gambaran permasalahan yang ditemukan di lapangan dengan tidak menggunakan angka-angka sehingga dapat ditarik kesimpulan. Pada prinsipnya penulis melakukan wawancara terhadap kakak perempuan yang dilangkahi, adik yang melangkahi, pemuka adat, niniak mamak, serta tokoh masyarakat dan masyarakat Tabu Baraie Nagari Paninjauan Tanah Datar. Sehingga penulis mendapatkan data-data, selanjutnya baru dilakukan analisa terhadap data tersebut kemudian didapatkan kesimpulan dari permasalahan tersebut.

\footnotetext{
${ }^{21}$ Sugiyono, Memahami Penelitian Kualitatif

(Bandung: Alfabeta, 2014), 227.
} 
Langkah-langkahnya adalah sebagai berikut: Pertama, menelaah data yang diperoleh dari informasi dan literatur terkait. Kedua, mengelompokkan data dan menyusunnya berdasarkan kategori. Ketiga, setelah data disusun dan diklasifikasikan, langkah selanjutnya adalah menarik kesimpulan berdasarkan data yang ada.

Teknik penjaminan keabsahan data yang digunakan adalah teknik trigulasi. Trigulasi teknik dalam penelitian untuk menguji kredibilitas dilakukan dengan cara mengecek data kepada sumbernya atau mempercayakan data kepada sumber yang sama dengan teknik yang berbeda. Mulamula penulis memperoleh data dengan wawancara kemudian diperiksa dengan observasi. Jika kedua teknik pengujian kredibilitas data menghasilkan data yang berbeda, maka peneliti melakukan diskusi lebih lanjut dengan sumber data yang relevan atau pihak lain, untuk memastikan data mana yang dianggap benar. Atau mungkin semuanya benar, karena sudut pandangnya berbeda. ${ }^{22}$

\section{PEMBAHASAN}

\section{Melangkahi Nikah Kakak Perempuan}

Melangkahi nikah terdiri dari dua kata yakni melangkahi dan nikah. Kata "melangkahi" berasal dari akar kata "langkah" yang diberi awalan "me" yang berarti melompat, mendahului atau melewati. Secara harfiah kata melangkahi mengandung tiga arti. Pertama;

22 Sugiyono, 274. melangkahi berarti mendahului pernikahan, yang kedua pelangkah adalah barang-barang yang diberikan oleh kedua mempelai kepada saudara laki-laki atau perempuan mereka yang didahului dengan perkawinan, dan yang ketiga; langkah yang berarti gerakan kaki ke depan atau ke belakang, jarak antara kedua kaki yang dikangkangi ke depan saat berjalan, tindakan awal berjalan. ${ }^{23}$ Dalam hal ini yang dimaksud adalah mendahului nikah atau kawin. Saudara yang usianya lebih kecil mendahului kakaknya dalam menikah. Tindakan adik yang mendahului saudaranya yang lebih tua untuk menikah ini yang disebut dengan melangkahi nikah.

Kemudian kata "melangkahi" dipadankan dengan kata nikah. Nikah yang dimaksud di sini adalah akad nikah. Secara jelas pengertian nikah ini tercantum dalam Pasal 1 Undang-undang Nomor 1 Tahun 1974 Tentang Perkawinan: ${ }^{24}$

"Perkawinan adalah ikatan lahir dan batin antara seorang pria dengan seorang wanita sebagai suami istri dengan tujuan membentuk keluarga (rumah tangga) yang bahagia dan kekal berdasarkan Ketuhanan Yang Maha Esa".

Selanjutnya kata "melangkahi nikah" disandingkan dengan kata "kakak perempuan". Secara khusus maksudnya adalah bahwa yang dilangkahi nikah

\footnotetext{
${ }^{23}$ Novianto HP, Kamus Lengkap Bahasa Indonesia, Cet. ke-1 (Surakarta: PT Bringin 55, 1999), 318.

${ }^{24}$ Undang-Undang Republik Indonesia Nomor 1 Tahun 1974 Tentang Perkawinan Dan Kompilasi Hukum Islam (Bandung: Citra Umbara, 2007), 2.
} 
adalah kakak perempuan. Secara umum gambaran melangkahi saudara dalam perkawinan ada beberapa bentuknya. Pertama, adik laki-laki melangkahi kakak laki-laki. Kedua, adik perempuan melangkahi kakak laki-laki Ketiga, adik laki-laki melangkahi kakak perempuan, dan keempat, adik perempuan melangkahi kakak perempuan.

Dalam bentuk yang pertama dan kedua, masyarakat memandang biasa seorang adik perempuan melangkahi kakaknya yang laki-laki dalam menikah. Juga bukan hal yang aneh jika adik lakilaki melangkahi kakak laki-lakinya. Akan tetapi bila yang terjadi sebaliknya, adik laki-laki melangkahi nikah kakak perempuannya (bentuk yang ketiga) atau adik perempuan melangkahi kakak perempuannya (bentuk keempat) dalam menikah. Hal ini dianggap tidak lazim. Adik laki-laki yang melangkahi kakak perempuannya, dipandang tidak bertanggung jawab atas kakak perempuannya. Dia dianggap melalaikan tugasnya sebagai seorang laki-laki yang seharusnya menjaga saudara perempuannya tersebut. Bahkan masyarakat memandang bahwa keluarganya tidak menghormati perempuan. Juga dipandang lebih buruk jika adik perempuan melangkahi kakak perempuannya untuk menikah. Di daerah Tabu Baraie Nagari Paninjauan Tanah Datar, pantangan melangkahi nikah kakak perempuan adalah bagian dari tradisi perkawinan.

Masyarakat Tabu Baraie Nagari Paninjauan Tanah Datar adalah masyarakat adat. Adat adalah salah satu komponen penting dalam sebuah masyarakat. Masyarakat pada umumnya dibentuk oleh adat. Kata adat berasal dari bahasa Arab yang berarti "adat kebiasaan". ${ }^{25}$ Yang dimaksud dengan kebiasaan adalah segala perilaku yang dilakukan orang dalam kehidupan sehari-hari yang tidak menyimpang dari norma-norma yang berlaku dalam masyarakat tersebut.

Berbicara tentang adat istiadat, masyarakat Jorong Tabu Baraie sangat menjunjung tinggi nilai-nilai adat Minangkabau yang telah mereka anut sejak nenek moyang mereka. Adat memiliki peranan penting dalam kehidupan masyarakat, karena adat merupakan cara hidup dalam mengembangkan hubungan antar anggota dalam masyarakat. Karena adat Minangkabau pada umumnya adalah peraturan dan hukum atau undang-undang, yang berlaku dalam kehidupan sosial masyarakat Minangkabau, khususnya yang hidup di alam Minangkabau, Sumatera Barat. $^{26}$

Di Minangkabau adat dibagi dalam beberapa jenis yaitu yaitu adat yang sabana adat, adat yang diadatkan, adat yang teradat dan adat istiadat.

\section{a) Adat yang sabana adat}

Adat nan sebana adat adalah kenyataan yang berlaku tetap di alam, tidak pernah berubah oleh keadaan tempat dan

\footnotetext{
${ }^{25}$ A Ridwan Halim, Hukum Adat Dalam Tanya Jawab (Jakarta: Ghalia Indonesia, 1989), 83. ${ }^{26}$ Djamanat Samosir, Hukum Adat Indonesia : Eksistensi Dalam Dinamika Perkembangan Hukum Di Indonesia (Bandung: CV. Nuansa Alia, 2013), 18 .
} 
waktu. Adat nan sabana adat tersebut pada kenyataannya mengandung nilainilai, norma dan hukum. Pada hakikatnya juga adat nan sabana adat ini menjadi sebuah kelaziman yang terjadi sesuai dengan kehendak Allah. Maka oleh sebab itu adat minangkabau tidak bertentangan dengan ajaran Islam, sesuai dengan falsafah adat basandi syara', syara' basandi kitabullah. Artinya adat tidaklah meninggi dari agama, aturan-aturan adat bersumber dari konsep-konsep ajaran Islam. Dengan kata lain adat nan sabana adat adalah adat yang sudah ada jauh sebelum adat yang lain tercipta, karena memang bersumber dari ketetapan Allah SWT.

\section{b) Adat nan teradat}

Adat nan taradat adalah ketentuan adat yang disusun di nagari untuk melaksanakan adat nan sabana adat dan adat nan diadatkan sesuai dengan keadaan dan kebutuhan nagarinya. Adat nan teradat disebut juga dengan adat babuhua sentak, artinya dapat diperbaiki, diubah dan diganti. Fungsi utamanya adalah sebagai pelaksana peraturan adat Minangkabau. 27 Sehingga aturan pelaksanaannya berbeda antara satu nagari dengan nagari lainnya berdasarkan permasalahan yang mereka hadapi, seperti yang dijelaskan oleh pepatah Minangkabau:

Lain lubuak lain ikannyo Lain padang lain ilalangnyo

${ }^{27}$ Maryelliwati and Wahyudi Rahmat, Sastra Minangkabau Dan Penciptaan Sebuah Karya (Padang Panjang: LPPMPP ISI, 2016), 17.
Lain nagari lain adatnyo Pepatah adat tersebut bermakna bahwa setiap tempat memiliki adat istiadatnya sendiri yang berbeda dengan tempat lain. ${ }^{28}$

\section{c) Adat nan diadatkan}

Adat nan diadatkan merupakan kebiasaan-kebiasaan yang bersifat normativ. Artinya kebiasaan yang harus diikuti oleh masyarakat, karena kebiasaan itu sesuai dengan kebutuhan masyarakat jorong tertentu. Kebiasaankebiasaan tersebut terkadang dikukuhkan dengan musyawarah oleh niniak mamak adat di sebuah nagari agar adat itu ditegakkan.

\section{d) Adat istiadat}

Adat istiadat adalah aturan adat yang dibuat atas kesepakatan niniak mamak dalam sebuah nagari berupa pedoman dan peraturan daerah yang telah diwariskan selama ini. Sesuai dengan falsafah waris nan dijawek, pusako nan ditolong. Artinya diterima oleh generasi sekarang dari generasi sebelumnya sehingga dapat berdiri kokoh. Adat istiadat umumnya muncul dalam bentuk kesenangan bagi anak nagari seperti seni, gaya dan tarian serta olahraga. Karena ini mencakup semua keinginan dan kesukaan anak nagari menurut aluau jo patuik. ${ }^{29}$ Sesuai pepatah, adat istiadat yaitu:

\footnotetext{
${ }^{28}$ Ibrahim Dt. Sanggoeno Diradjo, Tambo Alam Minangkabau (Tatanan Adat Warisan Nenek Moyang Orang Minang) (Bukittinggi: Kristal Multimedia, 2014), 148-49.

${ }^{29}$ Maryelliwati and Rahmat, Sastra Minangkabau Dan Penciptaan Sebuah Karya, 18.
} 
Dimano batang taguliang

Disinan tindawan tumbuah

\section{Dimano tanah dipijak}

Disinan langik dijunjuang

Maksudnya adalah seseorang harus menyesuaikan diri dengan adat yang berlaku di dalam masyarakat dimana ia tinggal serta menghormatinya.

Secara umum di Minangkabau dalam masalah pernikahan berlaku hukum Islam juga berlaku hukum adat. Sebagaimana yang dikemukakan oleh Van Vollenhoven

Hukum adat adalah keseluruhan kode etik positif yang di satu sisi memiliki sanksi. Adat umumnya tidak tertulis, tidak terkodifikasi, dan bersifat memaksa, serta memiliki sanksi. ${ }^{30}$

Jadi dapat dipahami bahwa hukum adat adalah peraturan-peraturan yang ada di suatu daerah tertentu atau adat-istiadat yang ada di suatu daerah yang didukung oleh masyarakatnya. Jika dilanggar maka ada akibat hukum (sanksi) bagi yang melanggarnya. Adat istiadat yang banyak berkembang di masyarakat diatur dalam hukum adat. Oleh karena itu, setiap daerah memiliki hukum adat. Mengenai perkawinan atau perkawinan, aturan adat perkawinan antara satu masyarakat adat berbeda dengan masyarakat lainnya. Adat istiadat suatu masyarakat dibangun di atas nilai-nilai yang dianut oleh masyarakat tersebut. Nilai-nilai tersebut diketahui, dipahami,

${ }^{30}$ Imam Sudiyat, Asas-Asas Hukum Adat (Yogyakarta: Liberty, th), 5. disikapi, dan dilaksanakan atas dasar kesadaran masyarakat. ${ }^{31}$

\section{Perkawinan Pantang Dalam Budaya Minang Kabau}

Dalam budaya Minangkabau juga dikenal istilah kawin pantang. Perkawinan pantang adalah perkawinan yang dilarang atau tidak diperbolehkan oleh masyarakat Minangkabau. Jika terus berlanjut, pelanggar akan mendapatkan sanksi adat. Perkawinan pantang dianggap merusak sistem adat karena dianggap merusak keharmonisan sosial. Bentuk-bentuk perkawinan pantang itu misalnya perkawinan sesuku meskipun tidak ada hubungan kekerabatan dan tidak berasal dari kampung halaman yang sama, menikahi seseorang yang telah diceraikan oleh kerabat, sahabat dan tetangga dekat, berpoligami dengan perempuan yang sekerabat, sepergaulan, dan setetangga, menikahi orang yang bertunangan, serta menikahi anak tiri saudara kandung.

Dalam realita masyarakat, selain lima contoh diatas, agaknya masih banyak bentuk-bentuk perkawinan pantang yang hidup dalam tradisi masyarakat. Dalam perkawinan pantang tersebut, jika ditemukan pelanggaran, maka kepada pelanggarnya akan dikenakan sanksi adat. Sanksi adat itu beragam bentuknya, Misalnya membubarkan perkawinan atau dibuang sepanjang adat. Maksudnya tidak diikutsertakan dalam kegiatan adat, diusir dari desanya, dan dikucilkan dari masyarakat. Sanksi adat dapat juga berupa

\footnotetext{
${ }^{31}$ Djazuli, Kaidah-Kaidah Fikih (Jakarta: Kencana Prenada Media, 2007), 78.
} 
denda yakni memberikan sejumlah uang yang besarannya ditentukan oleh ninik mamak. Selain uang denda adat ada juga berupa hewan. ${ }^{32}$

Selain perkawinan pantang, terdapat pula perkawinan sumbang yaitu perkawinan yang tidak ada larangan dan pantangannya, akan tetapi sebaiknya tidak dilakukan. Sama dengan perkawinan pantang, perkawinan sumbang juga merusak kerukunan sosial masyarakat adatnya. Untuk itu, masyarakatnya perlu menjaga keharmonisan sosial agar tidak tersinggung atau merasa terhina. Dalam perkawinan sumbang ini, yang terpenting adalah memelihara harga diri sesuai dengan falsafah raso jo pareso (rasa dan periksa) atau tenggang raso (toleransi).

Demikianlah gambaran perkawinan pantang di Minangkabau. Secara umum penerapannya berdasarkan falsafah raso jo pareso atau tenggang raso. Raso jo pareso dan tenggang raso diprioritaskan untuk menciptakan keharmonisan sosial di dalam masyarakatnya. Mengabaikan raso jo pareso dan tenggang raso, merusak tatanan hubungan sosial di antara masyarakatnya.

\section{Sosiologis Larangan Melangkahi Nikah Kakak Perempuan}

Agaknya berdasarkan falsafah raso jo pareso atau tenggang raso, pantangan melangkahi nikah kakak perempuan berlaku di Tabu Baraie Nagari Paninjauan Tanah Datar. Pantangan melangkahi nikak

\footnotetext{
${ }^{32}$ Asmaniar, Perkawinan Adat Minangkabau, Jurnal Binamulia Hukum Vol. 7 No. 2, 2018, 13637.
}

kakak perempuan tersebut dalam rangka menjaga kerukunan sosial diantara kakak beradik dan kehidupan sosialnya di dalam masyarakat. Seorang adik yang mendahului nikah kakak perempuannya, meskipun tidak dilarang oleh syarak, akan tetapi menjadi buah bibir di masyarakat. Melangkahi kakak perempuan dianggap aib dan melanggar norma kepatutan. Karena jika adik laki-laki melangkahi nikah kakak perempuannya, maka sebagai laki-laki ia dianggap tidak bertanggaung jawab atas saudara perempuannya. Jika adik perempuan yang melangkahi nikah kakak perempuannya, si adik dianggap tidak menghormati kakaknya. Sedangkan bagi si kakak perempuan yang dilangkahi, ia dianggap punya cacat atau kekurangan. Karena itulah perkawinan yang dilakukan dengan melangkahi saudara atau kakak perempuan yang belum menikah dianggap sebagai perkawinan yang kurang baik, ${ }^{33}$ meskipun syarak tidak melarang. Artinya adik yang mendahului nikah kakak perempuannya, maka sang adik dianggap telah melanggar norma adat meskipun tidak melanggar agama. ${ }^{34}$

Oleh karena itu melangkahi nikak kakak perempuan dianggap tindakan yang kurang baik. Kakak dan adik menjadi perbincangan di masyarakat, muncul image negative bagi si adik dan kakak yang dilangkahi. Terkhusus bagi kakak yang dilangkahi, image negative

\footnotetext{
${ }^{33}$ Zulkifli Labai Marajo (tungku ampek jurai pasukuan, suku Panyalai), Wawancara Pribadi, June 20, 2018.

${ }^{34}$ A. Datuak Djoampono (panungkek suku Panyalai ), Wawancara Pribadi, June 19, 2018.
} 
masyarakat tersebut, mempengaruhinya sehingga memutuskan tidak menikah.

Dengan demikian alasan terlarangnya melangkahi nikah kakak perempuan di Tabu Baraie Nagari Paninjauan Tanah Datar adalah dalam rangka menjaga kehidupan sosial si adik dan si kakak di lingkungannya. Karena melangkahi kakak perempuan, si adik dianggap tidak menghormati kakaknya yang belum menikah. Melangkahi nikah kakak perempuan adalah perkawinan yang melanggar norma adat, sehingga membebani bagi sang kakak. Hal ini dikhawatirkan sehingga hubungan adik dengan kakaknya tidak akan harmonis lagi. ${ }^{35}$

Faktor larangan lainnya adalah agar si kakak menemukan jodohnya. Dalam masyarakat Tabu Baraie Nagari Paninjauan Tanah Datar, bila ada perempuan belum menikah, sementara saudari-saudarinya semua sudah menikah. Hal ini dianggap tidak baik. Karena pasti menjadi buah bibir di kampungnya. Masyarakat berpandangan negatif terhadap kakak perempuan yang dilangkahi itu. Padahal si perempuan yang dilangkahi merasa biasa saja. Akan tetapi karena banyaknya pandangan miring masyarakat atas perempuan yang dilangkahi tersebut, maka lama kelamaan image negative itu mempengaruhi kondisi psikologisnya. Perempuan yang dilangkahi nikah, merasa tidak mendapat dukungan dari masyarakat sekitarnya. Dianggap tidak laku, punya cacat atau kekurangan. Anggapan-

${ }^{35}$ Dahniar (Ibu Rumah Tangga), Wawancara Pribadi, June 20, 2018. anggapan negative masyarakat pada akhirnya melukai perasaan perempuan, kurang percaya diri dan menutup diri sehingga dia tidak mau menikah. ${ }^{36}$ Kondisi seperti itu juga menghalangi orang lain menikahinya. ${ }^{37}$ Untuk menghindari hal semacam ini, maka diperlakukanlah larangan melangkahi nikah kakak perempuan. Dari data yang diperoleh berdasarkan wawancara dengan salah seorang panghulu, ${ }^{38}$ diketahui bahwa semua kakak yang dilangkahi oleh adiknya dalam perkawinan, sampai saat dilakukan penelitian masih belum menikah. Padahal usia kakak yang dilangkahi sudah melebihi usia produktif untuk menikah.

Menurut salah satu kakak yang dilangkahi, alasan dia belum menikah sampai saat ini adalah karena dilangkahi oleh adik, sehingga ia merasa malu kepada masyarakat, sebab perbuatan adiknya yang demikian dianggap telah melanggar adat. Pertanyaan masyarakat kapan menikah dan umur sudah sekian, menjadi beban mental. Apalagi kalau dibanding-bandingkan dengan adik yang telah menikah terlebih dahulu dan telah mempunyai anak, semakin lama membujang, tekanan mental semakin tinggi. ${ }^{39}$

Seiring dengan berjalannya waktu, masyarakat Tabu Baraie Nagari Paninjauan Tanah Datar juga mulai mengalami perubahan, meskipun falsafah

\footnotetext{
${ }^{36}$ Mar (salah seorang kakak yang dilangkahi), Wawancara Pribadi, July 8, 2018.

${ }^{37}$ Suhaimi (salah seorang kakak yang dilangkahi), Wawancara Pribadi, June 30, 2018.

${ }^{38}$ E.Dt Sidubalang (panghulu suku Panyalaian), Wawancara Pribadi, June 20, 2018.

${ }^{39}$ Syafril (salah seorang kakak yang dilangkahi), Wawancara Pribadi, July 8, 2018.
} 
adat Minangkabau Ndak Lakang Dek Paneh Ndak Lapuak Dek Hujan namun kenyataannya tradisi yang demikian tidak lagi relevan dengan keadaan. Sebab jika tradisi larangan melangkahi nikah kakak perempuan tetap dipertahankan, tentu banyak para adik harus menunda dahulu keinginannya untuk menikah, maka solusinya si adik diwajibkan membayar denda adat. Denda adat ditetapkan sebagai konsekuensi dari melangkahi nikah kakak perempuan. Denda adat itu berupa pakaian, uang atau emas. Denda yang diberikan berupa pakaian disebut dengan pakaian sapatagak, ${ }^{40}$ sedangkan jika yang diberikan adalah uang atau emas, diberikan kepada sang kakak berdasarkan kesepakatan antara mereka berdua saja. Denda ini dimaksudkan sebagai tanda permohonan maaf seorang adik kepada kakaknya karena telah melangkahi kakaknya terlebih dahulu untuk menikah.

Penting seorang adik memenuhi denda adat tersebut, sebagai tanda mengutamakan rasa saling menghargai sesama saudara sendiri, menimbang tingkah laku agar selalu disenangi, menjaga persatuan antara saudara kandung maupun masyarakat, memelihara budi agar senantiasa luhur, dan menjaga hubungan baik dengan niniak mamak serta melestarikan adat terdahulu. Dengan demikian denda tersebut dibuat untuk menciptakan rasa kepedulian dan menghargai yang lebih tua.

Dalam prakteknya pembayaran denda dilakukan sebelum proses akad

\footnotetext{
${ }^{40}$ Yang dimaksud baju sapatagak adalah pakaian lengkap berupa baju, kain, dan uang.
}

nikah sampai acara baralek selesai, jika dalam masa ini si adik belum juga membayar denda, biasanya mamak adat akan mengingatkan agar perasaan kakaknya yang dilangkahi tidak tersinggung dan menjaga hubungan persaudaraan tetap harmonis. Namun aturan ini hanya berjalan sementara, sebab seiring waktu perlahan-lahan, masalah membayar denda tidak lagi dipermasalahkan. ${ }^{41}$ Dalam banyak kasus masalah membayar denda sapatagak telah ditiadakan karena kerelaan hati sang kakak. ${ }^{42}$ Di samping itu juga, denda adat dianggap memberatkan si adik, sebab dia akan berumah tangga dan beban yang harus dia tanggung tentu lebih berat lagi. ${ }^{43}$

Karena melangkahi nikah kakak perempuan dianggap melanggar norma adat, sementara melanggar norma adat berarti pelanggaran dan merupakan aib. Bagi si kakak, hal seperti itu berdampak psikologis yang cukup berat. Sehingga si kakak merasa malu dan menjadi terbebani. Adanya larangan melangkahi kakak, secara sosial membuat si kakak yang dilangkahi diperbincangkan dengan ungkapan-ungkapan yang tidak baik seperti perawan tua. Padahal ini bukan kehendaknya, tapi masyarakatlah yang menghukumnya.

Sedangkan bagi adik yang melakukan pelanggaran adat, diberikan solusi dalam bentuk denda adat yang

\footnotetext{
${ }^{41}$ Dt. Gindo Mulia (Panghulu Suku Koto),

Wawancara Pribdi, June 20, 2018.

42 Yasri Amrina (salah seorang adik yang melangkahi, Wawancara Pribadi, July 8, 2018.

${ }^{43}$ Mar (salah seorang kakak yang dilangkahi), Wawancara Pribadi, June 30, 2018.
} 
diserahkan kepada kakak perempuannya yang dilangkahi. Sementara untuk si kakak, tidak menemukan solusi menghadapi kenyataan yang dianggap aib tersebut. Bahkan masyarakat menganggap diri si kakaklah yang beraib dan punya kekurangan. Sayangnya pihak keluarga tidak memberikan dukungan seutuhnya untuk kakak perempuan yang dilangkahi. Adat hanya memberikan solusi atas adik yang melangkahi dengan memberikan denda kepada kakak. Bahkan denda itu pun dihilangkan atas kerelaan hati kakak. Masyarakat adat tidak memberikan solusi atas kakak yang dilangkahi.

$$
\text { Agaknya ada ketimpangan }
$$

perlakuan adat atas solusi pelanggaran adat tersebut. Tidak ada solusi dalam masyarakat adat untuk si kakak perempuan yang dilangkahi. Apalagi seiring dengan berjalannya waktu, denda adat tidak diperlakukan atas dasar kerelaan hati kakak. Kenyataan tersebut menggambarkan bahwa pantangan melangkahi nikah kakak perempuan tidak lagi mengakar kuat.

Oleh karena itu perlu kiranya pihak keluarga, dalam hal ini ayah memaksimalkan kembali peranannya dalam menyelesaikan persoalan jodoh kakak yang dilangkahi. Tidak boleh ada pembiaran dari ayah. Kenyataannya di Tabu Baraie Nagari Paninjauan Tanah Datar, khususnya pihak keluarga menyerahkan sepenuhnya kepada si kakak perempuan tersebut perihal jodohnya. Jika ada calon yang datang melamar, keluarga tidak berkontribusi memberikan saran seutuhnya. Keputusan diserahkan secara penuh atas kakak yang dilangkahi. Karena dia dianggap sudah dewasa. Bisa menentukan siapa yang akan menjadi jodohnya. Agaknya tindakan ayah seperti itu tidaklah tepat, mengingat ia punya kewenangan ijbar atas anak perempuannya.

Dalam literature fikih, ijbar ${ }^{44}$ digambarkan sebagai hak ayah untuk mencari dan mengawinkan anak perempuannya dengan orang yang sepadan, bahkan ayah tidak perlu meminta persetujuan sang anak perempuan. Karena ayah diyakini pasti akan mencarikan pasangan terbaik untuk anaknya. Ayah tidak perlu meminta persetujuan anak perempuan atas calon jodoh yang dipilihkannya selama hubungan keduanya harmonis dan calon yang disiapkan ayah, sepadan dengan anak perempuannya. ${ }^{45} \mathrm{Jika}$ hubungan antara ayah dan anak perempuannya tidak harmonis, dan calon jodoh yang dipilihkan tidak sepadan, maka hak ijbar ayah menjadi gugur. Sebenarnya ijbar tidak harus diartikan paksaan, tetapi lebih cocok bila diartikan pengarahan. ${ }^{46}$ Dengan demikian makna hak ijbar adalah

\footnotetext{
${ }^{44}$ Disebutkan dalam banyak literature fikih, bahwa hak ijbar dimiliki ayah. Ayah dalam hal ini disebut dengan wali mujbir. Ayah memiliki hak mencarikan dan menikahkan anak perempuannya tanpa meminta persetujuan anak perempuannya terlebih dahulu. Kewenangan ayah yang luas ini menggambarkan betapa ayah sangat menginginkan kebahagian untuk anak perempuannya tersebut. ${ }^{45}$ Dalam konteks fikih kesepadanan dengan calon pasangan diistilahkan dengan kafa'ah. Kafa'ah merupakan syarat keharmonisan di dalam perkawinan dan bukan syarat mutlak. Semakin sepadan di antara suami isteri, semakin kuat terjalinnya keharmonisan dalam rumah tangga mereka., n.d.

${ }^{46}$ Beni Ahmad Saebani, Fiqh Munakahat

(Bandung: Pustaka Setia, 2009), 252.
} 
ayah mengarahkan siapa yang akan menjadi calon jodohnya dan bukan memaksakan. Pengarahan ayah tersebut harus dilakukan secara intensif dan mendalam. Untuk mengobati luka batin anak perempuannya atas image negative masyarakat atas dirinya.

Agaknya para ayah di Tabu Baraie Nagari Paninjauan Tanah Datar, tidak melakukan perannya dengan maksimal dalam penyelesaian jodoh yang dihadapi anak perempuannya yang dilangkahi nikah oleh adiknya. Hal ini diakui tuo kampung bahwa saat ini para orang tua menyerahkan urusan jodoh pada anakanaknya. ${ }^{47}$ Sekarang bukan lagi zaman Siti Nurbaya, anak-anak bebas menentukan jodohnya sendiri. Agaknya anggapan ini turut mempengaruhi atas melajangnya kakak perempuan yang dilangkahi nikah oleh adiknya.

Bukan hanya peran ayah yang memudar dalam mencarikan jodoh anak perempuannya, peran mamak atas kemenakan perempuannya juga hilang. Padahal di Minangkabau, perkawinan merupakan masalah bersama. Menikah merupakan urusan kerabat, keluarga, masyarakat, urusan pribadi satu sama lain dalam hubungannya yang sangat berbedabeda. ${ }^{48} \mathrm{Hal}$ ini menunjukkan bahwa urusan

\footnotetext{
${ }^{47}$ Bullah Dt. Rajo Ameh (Tuo Kampuang, (Dahulu, para perempuan menerima saja calon jodoh yang dipilihkan orang tua untuk mereka. Sekarang karena kemoderenan, orang tua menyerahkan sepenuhnya masalah jodoh pada anak-anaknya), Wawancara Pribadi, June 30, 2018.

${ }^{48}$ B Ter Haar Bzn, Asas-Asas Dan Susunan Hukum Adat (Jakarta: Pradnya Paramita, 1999), 159.
}

perkawinan dalam adat Minangkabau merupakan tanggung jawab bersama. ${ }^{49}$ Seorang mamak (sudara laki-laki dari pihak ibu) memikul tanggung jawab terhadap keponakan perempuannya yang belum menikah. Mempunyai gadih gadang (perawan tua) dalam sebuah keluarga merupakan aib. Sehingga harga diri kaum terhina dalam masyarakat. Meskipun aggapan ini sudah mulai pudar.

Secara prinsip, bagi orang Minang mencarikan jodoh untuk keponakan perempuannya juga menjadi tanggung jawab mamak. Sehingga pihak keluarga beserta mamak akan berusaha sekerasnya mencarikan jodoh untuk kemenakan perempuannya. Sehingga untuk kepentingan tersebut harta pusaka kaum boleh digadaikan. Dalam situasi yang mendesak, mereka hampir dapat mempertimbangkan berbagai kandidat tanpa memandang usia, selama itu sepadan dengan martabat sosial mereka. ${ }^{50}$ Oleh karena itu dengan kembali memaksimalkan peran mamak dalam kehidupan keluarga Minang, maka kakak perempuan yang dilangkahi tidak terlalu lama menjomblo. Tentunya keterlibatan mamak seperti itu dapat menjadi penawar atas luka batin yang dihadapi kemenakan perempuannya. Sayangnya peran mamak itu mulai tergerus secara perlahan.

\footnotetext{
${ }^{49}$ Asmaniar, Perkawinan Adat Minangkabau, 134.

${ }^{50}$ Asmaniar, Asmaniar, Perkawinan Adat

Minangkabau, 136-37.
} 


\section{KESIMPULAN}

Tabu Baraie Nagari Paninjauan Tanah Datar merupakan salah satu daerah Minangkabau. Di tempat itu masih berlaku tradisi pantangan melangkahi nikah kakak perempuan. Melangkahi nikah kakak perempuan dianggap sebagai perkawinan sumbang. Karena melangkahi nikah kakak perempuan merupakan pelanggaran atas norma adat. Melanggar norma adat berarti aib.

Bagi si adik yang melangkahi nikah kakaknya, aibnya dapat ditutupi dengan denda adat. Denda itu diserahkan dan diterima oleh kakak yang dilangkahi. Sedangkan bagi kakak, meskipun ia menerima denda adat, akan tetapi keadaannya yang sudah dilangkahi nikah oleh adiknya, tetap menjadi pembicaraan dan dianggap punya kekurangan. Image negative melekat pada diri si perempuan (kakak yang dilangkahi), sehingga ia menutup diri untuk menikah. kondisi ini semakin diperparah karena ayah tidak memaksimalkan tanggung jawabnya atas jodoh anak perempuannya tersebut. Mamak juga tidak cukup memainkan peran tanggung jawab kemamak-annya atas kemenakan perempuannya tersebut. Karena ayah dan mamak beranggapan bahwa si kakak perempuan yang dilangkahi sudah cukup dewasa dalam menentukan jodohnya.

\section{REFERENSI}

Ahmad Saebani, Beni. Fiqh Munakahat. Bandung: Pustaka Setia, 2009.

Arikunto, Suharsimi. Dasar-Dasar Evaluasi Pendidikan. Jakarta: Bumi Aksara, 2009.

"Arsip Nagari Paninjauan Geografi Dan Topografi Nagari," 2017.

Asmaniar. Perkawinan Adat Minangkabau, Jurnal Binamulia Hukum Vol. 7 No. 2, 2018.

B Ter Haar Bzn. Asas-Asas Dan Susunan Hukum Adat. Jakarta: Pradnya Paramita, 1999.

Djazuli. Kaidah-Kaidah Fikih. Jakarta: Kencana Prenada Media, 2007.

Dt. Sanggoeno Diradjo, Ibrahim. Tambo Alam Minangkabau (Tatanan Adat Warisan Nenek Moyang Orang Minang). Bukittinggi: Kristal Multimedia, 2014.

HP, Novianto. Kamus Lengkap Bahasa Indonesia. Cet. ke-1. Surakarta: PT Bringin 55, 1999.

(Ibu Rumah Tangga), Dahniar. Wawancara Pribadi, June 20, 2018.

Maryelliwati, and Wahyudi Rahmat. Sastra Minangkabau Dan Penciptaan Sebuah Karya. Padang Panjang: LPPMPP ISI, 2016.

(Panghulu Suku Koto), Dt. Gindo Mulia. Wawancara Pribdi, June 20, 2018. 
(Panghulu suku Panyalaian), E.Dt Sidubalang. Wawancara Pribadi, June 20, 2018 .

(Panungkek suku Panyalai), A. Datuak Djoampono. Wawancara Pribadi, June 19, 2018.

Ridwan Halim, A. Hukum Adat Dalam Tanya Jawab. Jakarta: Ghalia Indonesia, 1989.

Yasri Amrina. Wawancara Pribadi, July 8, 2018.

Mar. Wawancara Pribadi, July 8, 2018.

Suhaimi. Wawancara Pribadi, June 30, 2018 .

Syafril. Wawancara Pribadi, July 8, 2018.

Samosir, Djamanat. Hukum Adat Indonesia: Eksistensi Dalam Dinamika Perkembangan Hukum Di Indonesia. Bandung: CV. Nuansa Alia, 2013.

Sudiyat, Imam. Asas-Asas Hukum Adat. Yogyakarta: Liberty, th.

Sugiyono. Memahami Penelitian Kualitatif. Bandung: Alfabeta, 2014.

(tungku ampek jurai pasukuan, suku Panyalai), Zulkifli Labai Marajo. Wawancara Pribadi, June 20, 2018.

(Tuo Kampuang, Bullah Dt. Rajo Ameh. Wawancara Pribadi, June 30, 2018.

Undang-Undang Republik Indonesia Nomor 1 Tahun 1974 Tentang Perkawinan
Dan Kompilasi Hukum Islam. Bandung: Citra Umbara, 2007. 